\title{
A preventív és proaktív fogászati adatbázis bevezetése és jelentősége tömegkatasztrófa áldozat azonosításkor
}

\author{
Simon Botond ${ }^{1,3^{*}}$, Farid Ajang Armin², Vág János ${ }^{1,3}$ \\ ${ }^{1}$ Semmelweis Egyetem Konzerváló Fogászati Klinika, Budapest, Magyarország \\ ${ }^{2}$ Áldozatazonosító Szolgálat / Interpol DVI HUN, Budapest, Magyarország \\ ${ }^{3}$ SCRUNCH Kft., Páty, Magyarország
}

\begin{abstract}
Összefoglalás
A modern kriminalisztika interdiszciplináris területe a tömegkatasztrófa áldozat azonosítás. A katasztrófát általában egy előre nem látható esemény okozza, amelyben mind az emberi, mind pedig az anyagi kár jelentős. Napjainkban az áldozatazonosítás folyamata reaktív módon történik, tehát az azonosításhoz szükséges dokumentáció az esemény bekövetkezése után kerül összegyújtésre. A fogászati ante-mortem (AM) adatokat előre, hatóságilag egy központi adatbázisban, preventív jelleggel, kötelező módon nem tárolják.

A preventív AM adatbázis létrehozása felgyorsíthatja és költséghatékonnyá teheti az áldozatazonosítást, mert a jelenlegi reaktív módszer helyett preventív módon, proaktív jelleggel kerülne sor az azonosításra.
\end{abstract}

Kulcsszavak: emberi azonosítás, fogászati azonosítás, szájpadlás, digitális fogászat, adatbázis

\section{The introduction and importance of preventive and proactive dental identification in disaster victim identification}

\author{
Botond Simon ${ }^{1,3^{*}}$, Farid Ajang Armin² János Vág $^{1,3}$ \\ ${ }^{1}$ Semmelweis University Department of Conservative Dentistry, Budapest, Hungary \\ ${ }^{2}$ Disaster Victim Identification Service / Interpol DVI HUN, Budapest, Hungary
}

${ }^{3}$ SCRUNCH Ltd., Páty, Hungary

\begin{abstract}
Summary
Mass disaster identification is an interdisciplinary field of modern forensic science. A disaster is usually caused by an unforeseen event in which both human and material damage is significant. Nowadays, the victim identification process is reactive, i.e., the authorities react to the event that has occurred and collect the necessary documentation for identification after the event has taken place. Primary identifiers include fingerprints, DNA and dental records. In mass casualty incidents, teeth are usually the most common means of identifying victims. However, dental antemortem (AM) documentation is not stored in advance in a central database as a preventive measure.

The creation of a preventive AM database could speed up and make victim identification cost-effective, because it would be done in a preventive and proactive way instead of the current reactive method. The quality of the AM documentation would be guaranteed to be good and accurate, so that post-mortem (PM) data collected in the field can be easily and efficiently compared by a smart pattern recognition software, increasing the likelihood of successful identification. The introduction of digital health involves not only security and technology, but also cultural change. In Hungary, from 2020 onwards, the private sector will be obliged to provide data to the National eHealth Infrastructure (Elektronikus Egészségügyi Szolgáltatási Tér, EESZT), so digital health information will be stored in a centralized system, which can improve the quality of ante-mortem documentation. When identifying victims, it is important to have biometric identifiers that are resistant to environmental influences, have individual characteristics, are easy to collect and compare with reference information, and can be stored and used in a cost-effective way. The palatal ridge has been shown to meet the above properties. The development of digital dentistry and the involvement of the dental sector in data collection will facilitate the work of forensic dental experts, enabling the state to ensure effective identification and subsequent dignified farewells and burials for its citizens in the event of a mass disaster. According to the principle of operation of the preventive AM-PM database, the two- and three-dimensional X-ray
\end{abstract}


and other imaging data, findings, anamnesis documentation and final reports collected during the lifetime of a citizen are stored in a central database. Changes during screening examinations can be traced. One of the most valuable is dental documentation. All information linked to the individual is stored with AM ID, which is also linked to passport and ID card information. In the event of an accident, post-mortem data is also stored in the AM-PM database, which is saved with a PM ID. With the help of a smart algorithm, the AM-PM ID match helps to identify the victim. In the case of missing persons, it is important that the missing person's medical AM documentation, if not already stored, is immediately included, since when identifying an unknown body, it is probably best to start the search among the missing persons first.

Keywords: human identification, dental identification, palate, digital dentistry, database

\section{Bevezetés}

A tömegkatasztrófák az emberi civilizációban állandóan visszatérő jelenségek, függetlenül attól, hogy természeti csapás, emberi mulasztás, baleset vagy terrorcselekmény okozza. Jellemző a tömegkatasztrófákra az is, hogy az áldozatok száma a bekövetkező katasztrófa jellegétől függően a több tízes számtól a több százezres számig is terjedhet. Világméretű kihívás a katasztrófák elleni védekezés, katasztrófák utáni helyreállítás és a terrorcselekmények megakadályozása. Az áldozatok és a terroristák azonosítása csak nemzetközi összefogással együtt sikerülhet, hiszen a természeti katasztrófák és terrorcselekmények országhatárokon átnyúló komplex folyamatok.

Az azonosítás szempontjából meg kell különböztetnünk, hogy áldozatról vagy elkövetőról beszélünk. Az elkövetők esetében szintén fontos, hogy az azonosításkor még élő vagy már halott az illető. A következőkben az áldozatazonosítás biztonsági kihívásairól, sikerességének lehetséges módjáról írunk, majd röviden ismertetjük a biometrikus, szájpadlásalapú azonosítási módszert, amelyet korábbi kutatásunkban, egypetéjű ikerpárok bevonásával bizonyítottunk.

\section{Az áldozatazonositás kibívásai}

A modern kriminalisztika interdiszciplináris területe a Disaster Victim Identification (DVI), azaz a tömegkatasztrófaáldozat-azonosítás. A legismertebb DVI kézikönyv (DVI Guide) az Interpol módszertani útmutatója, amely protokollok szerint írja le az áldozatazonosítás menetét (Interpol 2018). Az Interpol filozófiájához hozzátartozik, hogy standardizált eljárások útján, folyamatos szervezéssel és képzéssel, mindenekelőtt a kegyeleti, kulturális és emberiességi jogokat szem előtt tartva interdiszciplináris szemléletmóddal a lehető leghatékonyabb módon azonosítsa az áldozatokat. A tömegkatasztrófát általában egy előre nem látható esemény okozza, amelyben mind az emberi, mind pedig az anyagi kár jelentős.

A nagy esetszám és a maradványok biológiai bomlásának gyors lefolyása miatt, az időfaktor és a fertőzésveszély nagyon fontos szerepet játszik. A katasztrófák száma megsokszorozódott az elmúlt évtizedekben
(Vanderveken et al. 2016), körülbelül 1,23 millió ember életét követelte, és több mint 4 milliárd ember életére volt kihatással. Az emberéletek mellett pedig jelentős anyagi kár keletkezett, amely a 3000 milliárd dollárt is megközelítette (Affairs 2020).

Az áldozatazonosítást DVI szempontból az is meghatározza, hogy az adott esemény zárt vagy nyílt körben történik. Az előbbihez tartozik, amikor az áldozatok személye egy zárt csoporton belül ismert, mint például a Hableány hajóbaleset (2019c) vagy az etióp légi katasztrófa (2019b) esetében. Nyílt eseménynek tekintjük, amikor az áldozatok többségéról nem tudjuk, hogy a katasztrófa bekövetkezésének pillanatában a helyszínen tartózkodtak-e, vagy sem. Számos olyan terrorcselekményhez köthető esemény történt az elmúlt években, amelyben az áldozatok származási országa és pontos kilétének ismerete komoly kihívás elé állította a hatóságokat. Ezekben az esetekben határokon átívelő együttműködésre volt szükség, ez történt Brüsszelben (2016c), Nizzában (2016b), Berlinben (2016a), Stockholmban (2017b), Barcelonában és Cambrilsban (2017a), az ÚjZélandi Christchurch városában (2019a) és Bécsben (2020b). Hasonlóan Beirutban (2020a) vagy Taiwanon (2021c) is, ahol elsősorban emberi mulasztás okozta a tragédiát.

2004 decemberében Délkelet-Ázsiában egy 9,1-es erősségű tengeri földrengés okozta szökőár közel 230000 ember halálát követelte, amely a modern kori természeti katasztrófák között az egyik legnagyobb számú halálos áldozattal járó nyíltkörű esemény volt. A helyzet súlyosságát az is mutatta, hogy az egyik legnagyobb nemzetközi összefogásra (Angyal-Petrétei 2019a) volt szükség ahhoz, hogy az áldozatokat minél rövidebb időn belül azonosítani lehessen. A katasztrófában érintett országok állampolgárainak azonosítása érdekében minél gyorsabban a helyszínre kellett delegálni a DVI egységeket, azonban 2004-ben egyes országok nem voltak felkészülve ilyen típusú eseményre, ezért a DVI egységek mérete jóval elmaradt a szükségestől. Egy speciálisan kiképzett DVI egység szenior DVI csapatvezetőből, rendőrökből, igazságügyi szakértőkből, igazságügyi fogorvos szakértőkből, ujjnyomat és DNS-elemzőkből, valamint egyéb, a DVI egység munkáját segítő szakemberből áll (Interpol 2018). A DVI egységek a protokollt 
követve a következő PM adatokat gyưjtik be: DNS-minta, ujjnyomatminták, személyes tárgyak, részletes fogászati státusz, valamint fogászati röntgenfelvételek (Schuller-Götzburg-Suchanek 2007).

A helyszínen felállították a TTVI-IMC-t (Thai Tsunami Victim Identification-Information Management Center) vagyis egy olyan menedzsmentközpontot, amely az áldozatazonosítást - a helyszínen begyújtött mintákat az ante-mortem (AM) adatok összehasonlítása céljából - és a tájékoztatást koordinálta (Schuller-Götzburg et al. 2005). Az áldozat személyét három primer azonosítási adat: ujjnyomat, DNS-minta, valamint fogászati státusz alapján határozzák meg (Interpol 2018). Az adatösszevetés akkor tekinthető sikeresnek, ha az AM és PM adatokban megfelelő egyezőséget találnak.

Az igazságügyi szakértők a Phuket környéki katasztrófa helyszínén talált 4280 áldozatot speciális hưtőkonténerben helyezték el. Az áldozatoktól gyưjtött mintákat 15 hónap alatt dolgozták fel, így 2044 külföldi személyból 1847-et azonosítottak (90,36\%), az 1603 thai állampolgárból pedig 1193-at (74,42\%) (Schuller-GötzburgSuchanek 2007). Az azonosítási folyamat elhúzódásának egyik oka az volt, hogy összesen 2 fogorvos szakértő vitte be a helyszínen gyüjtött adatokat a számítógépes rendszerbe. Az automatizált szoftveres rendszer az AM és PM adatokat összehasonlította, és az adategyezőség szempontjából az alábbi kategóriák egyikébe sorolta be: „valószínu””, „bizonyított”, „lehetséges”, „nem elegendő bizonyíték” vagy „kizárt”. Egy igazságügyi fogorvos szakértő átnézte a szoftver által értékelt eredményeket, majd a thai hatóságok is ellenőrizték az eredményeket. Az áldozat személyének megállapítása után állították ki a halotti bizonyítványt (Schuller-Götzburg-Suchanek 2007). Napjainkban a közösségi médiának is szerepe van a veszélyhelyzeti reagálás felgyorsításában (Palen-Hughes 2018). Előnye, hogy a közösségimédia-felületekre feltöltött, veszélyhelyzettel kapcsolatos videós és képi tartalmak az esemény rekonstruálását segíthetik, hátránya ezzel szemben, hogy az információ gyors és szabad áramlásának köszönhetően a hatóságokat komoly nyomás alatt tartja a krízismenedzsment oldaláról (Alexander 2014). Tehát a közösségi média újabb kihívás elé állítja a DVI egységeket, mivel civil oldalról magas fokú az elvárás a krízismenedzsment felgyorsítása érdekében tömegkatasztrófaáldozat-azonosítás esetén is (Houston et al. 2015).

Az esemény vagy szerencsétlenség helyszínén a fogászati adatok felvétele az Interpol PM 600's formanyomtatványán történik, a legtöbb esetben analóg módon, amelyet utólag digitalizálnak. A státuszfelvételt főleg kétdimenziós fotódokumentációval, valamint röntgenfelvétel készítésével egészítik ki. A szemfogak eltávolításából nyernek DNS-mintát, amennyiben a szemfogak sérültek vagy hiányoznak, úgy a premoláris fogakból. Szemben az ujjnyomatok és a DNS alapján történő azonosításokkal egyre több azonosítás történik fogászati módszerrel (Schuller-Götzburg-Suchanek 2007). Gyermekek esetén a tej- vagy vegyes fogazat, idősek esetében pedig a jelentós fogvesztés nehezíti az ante- és post-mortem összevetés eredményét. Az összevetést, és így az azonosítás sikerességét, nagyban befolyásolja az adott ország egészségügyi adminisztrációs rendszere. Fontos tényező, hogy milyen minőségben és mennyiségben állnak rendelkezésre AM-adatok az állampolgárokról, valamint a rendelkezésre álló információk milyen mértékben digitalizáltak, standardizáltak és könnyen kereshetők. Komoly nehézséget jelentett a 2004-ben bekövetkezett cunami-katasztrófa áldozatazonosításai során, hogy fogászati AM-adatok alig álltak rendelkezésre az indonéz állampolgárokról (Angyal-Petrétei 2019a). Amennyiben egy ország állampolgárairól naprakész, pontos, digitális, biometrikus adat áll rendelkezésre, akkor a tömegkatasztrófa esetén bekövetkező áldozatazonosítást fel lehet gyorsítani. Ehhez viszont elengedhetetlen, hogy az egyes országok megfelelően kiképzett DVI egységekkel rendelkezzenek.

\section{Az Áldozatazonositó Szolgálat létrehozása}

A nemzetközi elvárások a magyar Áldozatazonosító Szolgálat létrehozását felgyorsították, és 2018-ban a Készenléti Rendőrség Nemzeti Nyomozó Iroda irányítása alatt megalakult a DVI Hungary, azaz a magyar Áldozatazonosító Szolgálat (Angyal-Petrétei 2019a; Angyal-Petrétei 2019b). A DVI Hungary célja, hogy megfelelően és folyamatosan képzett szakemberekkel, a szükséges eszközökkel és logisztikával rendelkező, erős jogszabályi felhatalmazással bíró, bármikor bevetésre kész áldozatazonosításra felkészült egység jöjjön létre.

\section{Az ante-mortem dokumentáció begyüjtésének lehetöségei Magyarországon}

Az ante-mortem egészségügyi adatok az emberi élet során elegendő mennyiségben keletkeznek, ugyanakkor az adatminőség és a rendelkezésre állás komoly szabályozást igényel. Az egészségügyi adatok átláthatóságára tett törekvést erősíti, hogy Magyarországon létrejött az Elektronikus Egészségügyi Szolgáltatási Tér (EESZT), amely felépítésében alkalmas arra, hogy áldozatazonosítás esetén az állampolgárokra vonatkozó fóbb adatok, egészségügyi információk, kezelési jellemzók segítsék a hatóságok munkáját. Az EESZT létrehozásáról szóló törvényjavaslatot 2015-ben fogadta el az Országgyuulés, majd 2017-ben elindult a rendszer tesztelése, 2020-tól pedig a magánszolgáltatóknak is kötelezővé vált a csatlakozás (2021a). A magyar kormány 2020-ban elfogadta Magyarország Mesterséges Intelligencia Stratégiáját (MI Stratégia), melynek célkitúzései között hangsúlyosan szerepelt, hogy Magyarország adatgazdaságát fel kell építeni és a koordinált adatgyúijtést el kell indítani. A jövóben pedig a nemzeti adatvagyon koordinációjáért a 
Nemzeti Adatvagyon Ügynökség (NAVÜ) lesz a felelős (2020c). Az EESZT, az MI Stratégia és a NAVÜ összehangolt múködése mind szerepet játszhat egy jövőben bekövetkező katasztrófahelyzetre való felkészülésben. Ezek az irányok abban segítenek, hogy az állampolgárok és az állam ne csak passzív szereplói legyenek a rendszernek, hanem proaktívvá váljanak. Ugyanakkor az ilyen irányú digitalizáció számos veszélyt, szabályozási kérdést és megoldatlan problémát támaszt a döntéshozók, hatóságok és az ország elé, hiszen a digitális egészségügy nemcsak technológiai, hanem kulturális változásokkal is jár, amelyben mindenkinek kicsit átalakul a szerepe (Meskó et al. 2017).

\section{Az ante-mortem adatok begyüjtésének két fó pillére Magyarországon}

A megfelelő mennyiségú adatgyújtéshez idő és kellően nagy számú mintapopuláció is szükséges. Magyarországon a jelenleg is hatályos 26/1997. (IX. 3.) az iskolaegészségügyi ellátásról szóló NM rendelet szerint a 3-18 éves korosztályt preventív jellegû egészségügyi alapellátásban kell részesíteni, amely kiterjed valamennyi nevelési-oktatási intézményre (1997a). Az óvodáskorú gyermekeknek évente egyszer, iskoláskorú gyermekeknek pedig évente kétszer kötelező a fogászati szürővizsgálat, szükség esetén a terápiás ellátás. A 3-18 éves korosztálytól éves szürővizsgálattal nyert adatok digitális tárolása már rövid idő alatt megfelelő mennyiségú információval láthatja el az ante-mortem adatbázist, amely akár 5-10 év alatt preventív módon egy katasztrófahelyzet bekövetkezésekor szolgálhatja az áldozatazonosítás sikerességét.

A katonai szolgálatra való egészségi, pszichikai és fizikai alkalmasságról, valamint a felülvizsgálati eljárásról szóló 10/2015. (VII. 30.) HM rendelet szerint a honvédek évente egészségalkalmassági vizsgálaton esnek át, amely a fogászati szúrővizsgálatra is kiterjed (2015). A fogazati állapotot a NATO STANAG 2466 szabvány szerint értékelik, a fogstátuszt a NATO szabvány szerint a PAV lapon rögzítik (NATO 2017). Kiemelt prioritásnak tekintik, hogy az ország haderejében harcoló honvédek kiváló egészségi állapotban legyenek, amelybe a megfelelő fogászati egészségi állapot is beletartozik (Suri 2010).

Látható, hogy mind a hivatásos állomány, mind pedig a civil személyek ante-mortem dokumentációjának begyújtéséhez megvannak az alapok. Azonban koordinált, szoftveres és szakmai oldalról támogatott protokollra van szükség, hogy a hazai ante-mortem adatbázis felépülhessen és a jelenlegi reaktív módon múködő áldozatazonosító rendszert preventív és proaktív módon müködő modell váltsa le.

\section{A reaktio áldozatazonositástól a preventio és proaktín áldozatazonositásig}

Az igazságügyi fogászati azonosítás reaktív módon történik, azaz a megtörtént eseményre reagálnak a szakemberek, és megpróbálnak a lehető legtöbb információhoz hozzájutni, hogy minél pontosabban beazonosíthatóvá váljon az áldozat. Ezzel szemben az AM-adatok minőségi begyújtése messze elmarad a 2l. századi adatgyújtés lehetôségeitől, így az igazságügyi fogorvos szakértóknek jó minőségü, számos információforrással rendelkező PM-adatot kell hasonlítani egy gyenge minőségú, kevés információforrással rendelkező AM-adathoz. A fogászati azonosításkor a töméseket, gyökérkezeléseket és implantátumokat hasonlítják össze. Feltételezhető, hogy nincs két olyan ember a világon, akinek megegyezne a fogazati státusza. Az azonosítást tovább nehezítheti, ha az áldozatot elhamvasztották. A hamvasztás $800{ }^{\circ} \mathrm{C}-1000^{\circ} \mathrm{C}$ között történik (Absolonova et al. 2012). $1000{ }^{\circ} \mathrm{C}$ felett már csak az egyes implantátumcsavarok maradnak meg, azonban az implantátumok felszínén vagy belsejében nincsen sorozatszám, amely alapján azonosítani lehetne az áldozatot. A fogászati implantátummal rendelkezók száma folyamatosan növekszik a világon, az előrejelzés szerint a fogászati implantátumok elterjedtsége 2026-ra elérheti az amerikai lakosság körében a 23\%-ot (Elani et al. 2018). Az implantátum behelyezési trendeket látva az Interpol 2019-ben egy állásfoglalást adott ki azzal kapcsolatban, hogy a térd- és csípőimplantátumokhoz hasonlóan (Vieira et al. 2012) a fogászati implantátumokat is sorozatszámmal lássák el a gyártók, valamint az egyes országok hozzanak létre implantátum regisztereket a pontos dokumentáció végett, amely természetesen az implantátumok eltávolításának idejét és okát is tartalmazza. A Központi Implantátumregiszterról szóló törvény Magyarországon 2014. január l-jén lépett hatályba. A regiszter létrehozásának jogszabályi alapjait a 2013. évi CXXVII. törvény teremtette meg (2013), az adatfeltöltést pedig az 1997. évi CLIV. törvény 101/C. \$ alapján szabályozzák (1997b). A hatósági ellenőrzést az Országos Gyógyszerészeti és Élelmezés-egészségügyi Intézet (OGYÉI) végzi, amelyben a szolgáltatók nyilvántartással kapcsolatos kötelezettségeinek teljesítésére helyezi a hangsúlyt (2021b).

A megoldást az jelentheti, ha az adatgyüjtés preventív módon valósul meg és a Magyar Állam kötelezi a fogorvosokat, fogtechnikusokat és a lakosságot az éves adatszolgáltatásra szűrővizsgálat keretén belül. Ekkor felépülhet egy olyan adatbázis, amely tárolja a biometrikus elemeket, amelynek segítségével tömegkatasztrófa esetén rövidebb idő alatt, automatikusan lehet összehasonlítani az AM- és PM-adatot. Az AM-adat a preventív elvek miatt elégséges információval bír, így adatminőség szempontjából a PM-adattal megegyezhet, ezáltal proaktív módon támogathatja az áldozatazonosítást. Nemzetközi 
szinten pedig a magyar példa jó gyakorlatként szolgálhat az Európai Unión belüli és kívüli államok preventív egészségügyi adatgyưjtésének előmozdítása érdekében.

\section{Az ikrek szerepe a biometrikus azonositás fejlesztésében}

A világ lakosságából nagyjából 140 millióra tehető az ikerpárok száma, amelyekből 32 millió egypetéjü iker (Monden et al. 2021). A legfrissebb tanulmány szerint az 1980-as évek óta az ikerterhességek aránya világszerte egyharmadával, 9,1-rôl 12,0-re nőtt 1000 szülésből, ami évente körülbelül 1,6 millió ikerpárt jelent. Az egypetéjüek esetében enyhe emelkedés figyelhető meg, itt az arány 4 az 1000 szülésból (Monden et al. 2021; Pison et al. 2015).

Az egypetéjű ikrek hasonlósága a fenotípusos azonosítást nehezíti (Martini et al. 2015), ujjnyomatuk nem azonos, de nagymértékben hasonlít (Tao et al. 2012).
Fontos találni olyan biometrikus jegyet, amely nagyobb hatékonysággal képes megkülönböztetni az ikerpár tagjait egymástól.

Korábbi publikációnkban sikerült bizonyítanunk, hogy egypetéjű ikreket a szájpadlásbordázat alapján 99,999\%-os populációs lefedettséggel, 99\%-os megbízhatósággal meg lehet különböztetni egymástól, digitális háromdimenziós mintákat használva, annak ellenére, hogy az ikerpár tagjai közel 100\%-ban azonos genetikai állománnyal rendelkeznek (Simon et al. 2020). A digitális összehasonlító módszer pedig a biometrikus azonosítást új alapokra helyezi, nem jár invazív beavatkozással, mintázatfelismerő szoftver segítségével költséghatékonyan, nagyfokú megbízhatósággal dolgozik, és ismert, hogy a fogak és a szájpadlásbordázat hosszú távon stabil, azonosításra alkalmas képletek (Azab et al. 2016; Chong et al. 2020; Kapali et al. 1997; Kommalapati et al. 2017; Limson-Julian 2004; Taneva et al. 2017; Taneva et al. 2015).
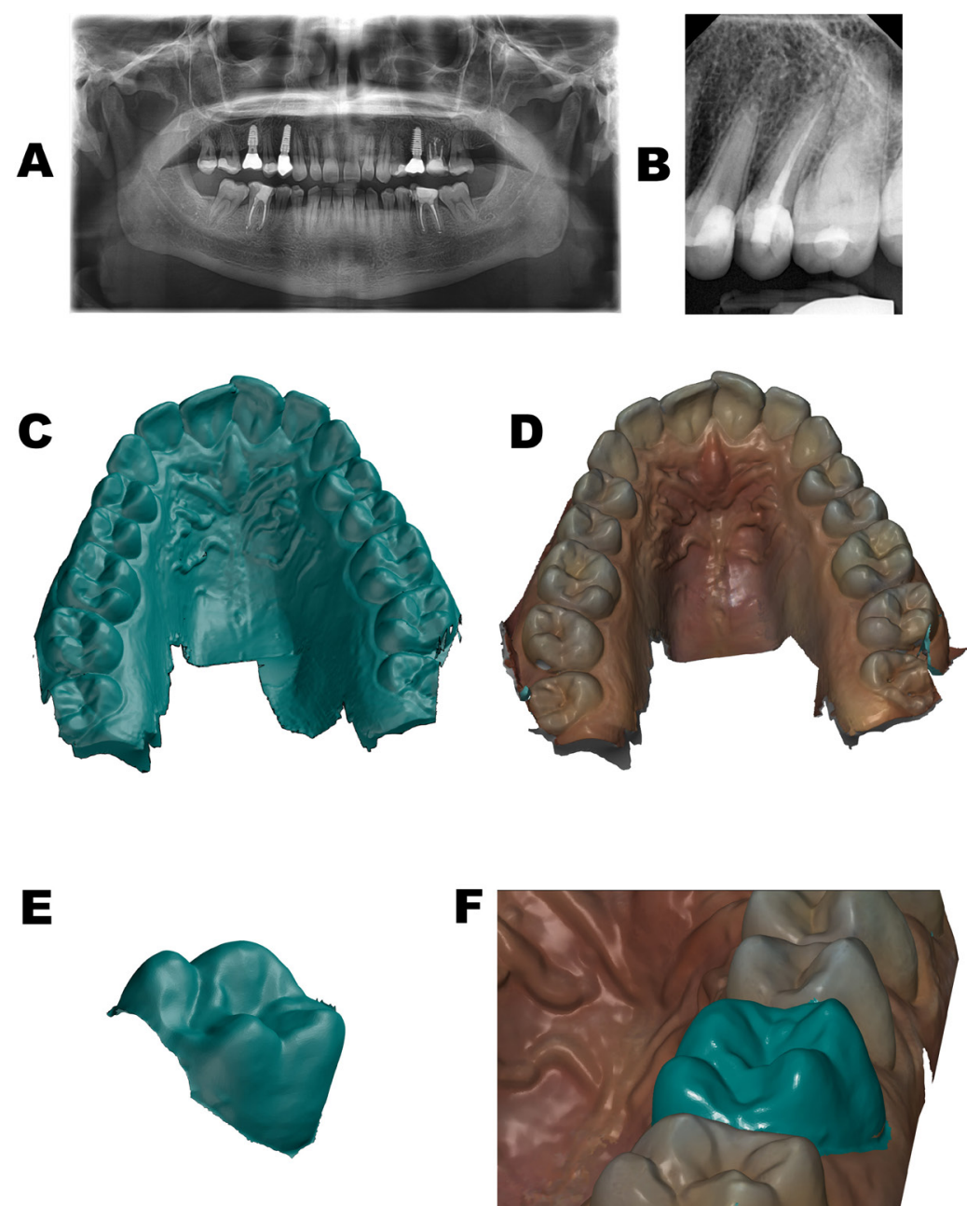

1. ábra

A fogászati 2D- és 3D-adatok típusai. Az A képen panoráma, a B képen intraorális röntgenfelvétel látható. Ez utóbbira jellemző, hogy egy vagy több fog fér bele a röntgenképbe, amelyen a gyökér körüli, úgynevezett periapicalis terület, valamint a koronai rész is látható. A $\mathbf{C}$ képen a háromdimenziós digitális szken monochromatikus, azaz egyszínú verzióban, valamint a $\mathbf{D}$ képen ugyanennek a szkennek a színes változata. Az $\mathbf{E}$ képen egyfogas $3 \mathrm{D}$ digitális szken látható, az $\mathbf{F}$ képen pedig az $\mathbf{E}$ képen látható fog, és ugyanannak a személynek a színes szken (F) egymásra vetített verziója látható. Mindegyik fogászati képinformáció segíti az azonosítást

Forrás: A szerző saját ábrája 
Ha a fogászati szakma bevonásával, szájszkenner segítségével begyüjtésre kerül a szájpadlást és a fogakat is tartalmazó háromdimenziós információ, akkor felépíthető egy megbízható ante-mortem adatbázis, amelynek legfóbb célja, hogy szükség esetén hozzáférhető információval szolgáljon az Áldozatazonosító Szolgálatnak, az Interpolnak, valamint a hazai és nemzetközi rendvédelmi hatóságoknak.
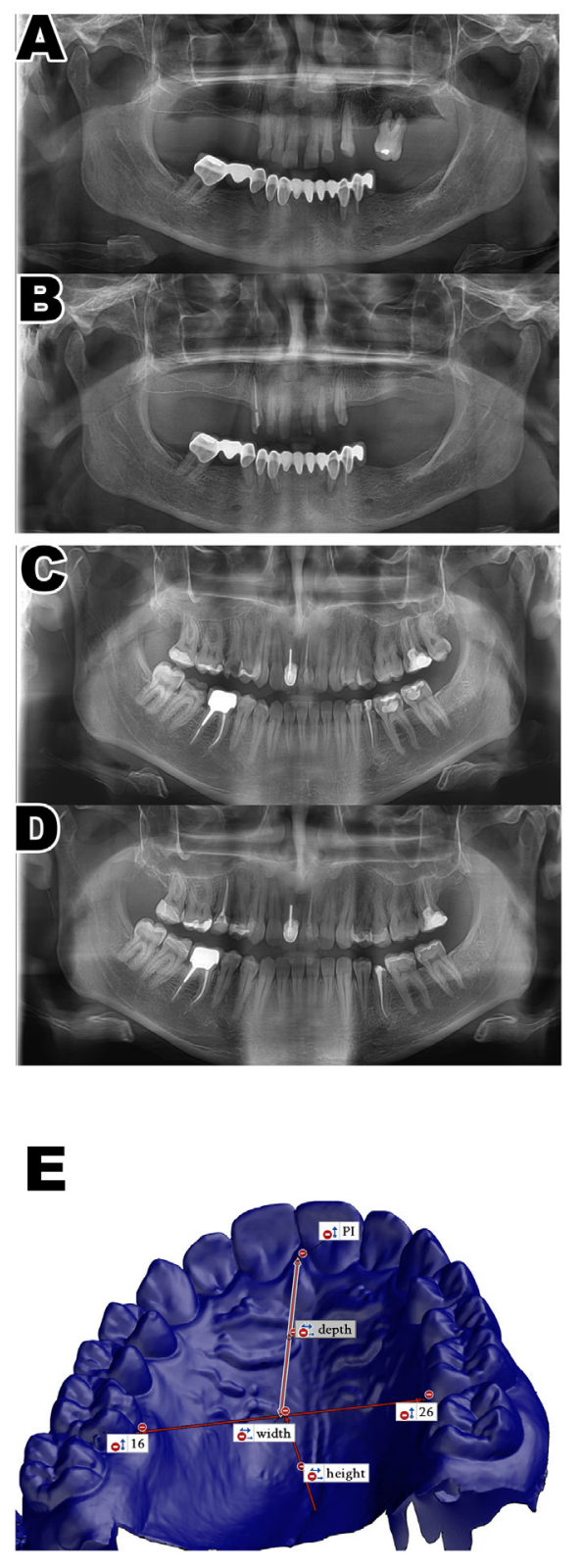

\section{A preventív fogászati azonosítási rendszer felépítése}

A digitalizáció a mindennapjaink részévé vált, amely az egészségügyben is számos innovatív megoldást eredményezett. Magyarországon az EESZT bevezetésével kötelező szinte minden egészségügyi adat feltöltése, de a fogászati $2 \mathrm{D}$ - vagy $3 \mathrm{D}$-leletek, mint például a panoráma-
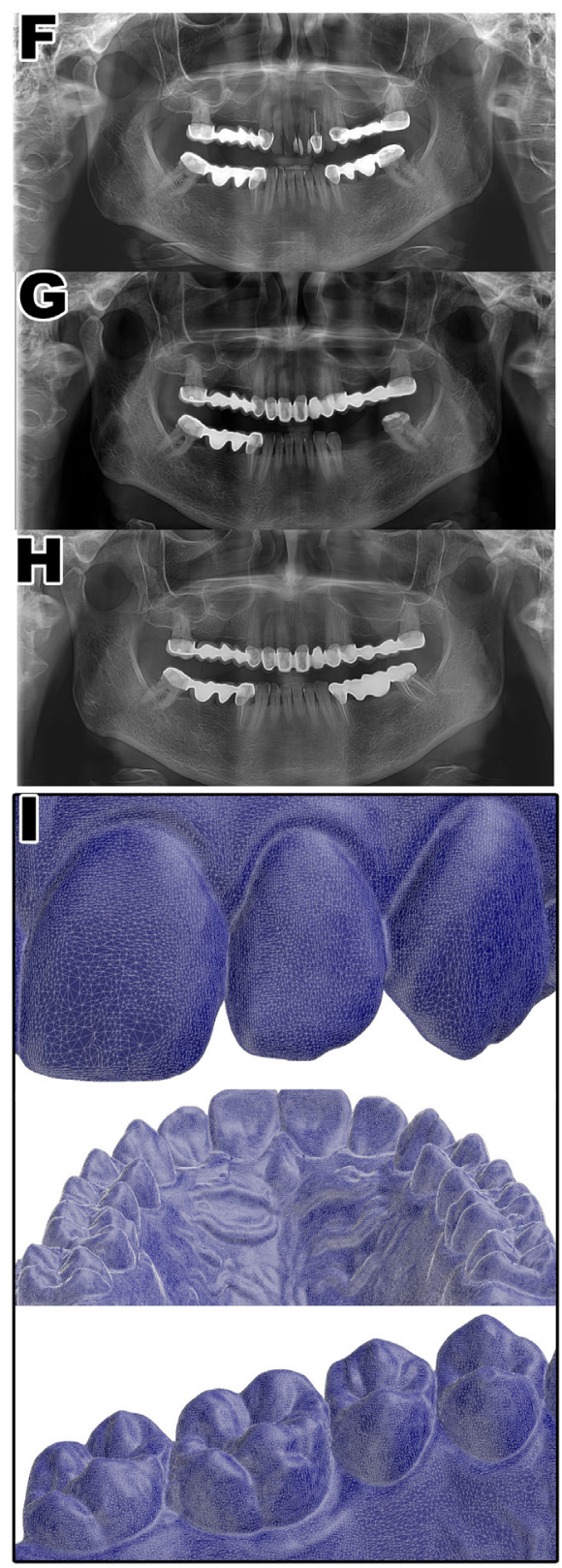

2. ábra

2D és 3D fogászati felvételek. Az A és B kép ugyanattól a személytől származó, két külön időpontban készült panorámaröntgen-felvétel. A C és D kép ugyanattól a személytől származó, két külön időpontban készült panorámaröntgen-felvétel. Az F, G és H kép ugyanattól a személytől származó, három külön időpontban készült panorámaröntgen-felvétel. A B képen látható, hogy a felső fogakat érte nagyarányú módosítás a fogeltávolítás, fogkorona csiszolás, valamint gyökérkezelés következtében, míg az alsó fogív érintetlen maradt. A D képen szintén olvan fokú módosítások történtek mind az alsó, mind pedig a felső fogívben, hogy ez akár negatív módon befolyással lehet az AM-PM adatösszevetési folyamatra. Az F és H képet összehasonlítva látható, hogy a jobb alsó és felső fogívben található hidak változatlanul maradtak, azonban a bal oldal teljesen megváltozott. Amenynyiben csak a bal oldalról érhető el AM információ (F), és a PM információval $(\mathbf{H})$ összevetés történik, függetlenül attól, hogy ugyanattól a személytôl származik, ronthatja az egyezőség esélyét. A $2 \mathrm{D}$ információ mellett fontos a $3 \mathrm{D}$ információ eltárolása (I), amely a fogformákat, rágófelszíni karakterisztikát, valamint a szájpadlásbordázatot tekintve egyedi képet ad minden ember esetében. A 3D információ mellett pedig az egyes szájpadlás-paraméterek automatikus lemérése és eltárolása szintén növelheti az egyezőség biztonságát (E)

Forrás: A szerző saját ábrája 
röntgen-felvétel vagy az intraoralis röntgenfelvétel, valamint a 3D digitális minta feltöltése nem kötelező ( 1 ábra).

Önmagában nem jelent megoldást a leletek feltöltése, ha nem kerül kialakításra egy olyan okos (smart data) rendszer, amely olvasni, értelmezni és kategorizálni tudja az egyes 2D- és 3D-információkat. Szoftveres analizálást követően a megfelelő címkével lehetne ellátni a feltöltött képet, amely így kereshetővé válna egy óriási big data adatbázisban. Tömegkatasztrófa-helyzet esetében a címkék alapján a lehetséges egyező személyeket automatikusan képes lenne kiválogatni a szoftver, hogy az igazságügyi szakértőnek már csak egyeztetnie kelljen az AM- és PM-adatokat, és eljuthasson a sikeres összevetésig (Pinchi et al. 2012), amelyet idővel egy mesterséges intelligencia algoritmus automatikusan felismer és segíti az összevetési folyamatot (2. ábra).

A digitális technológia exponenciális növekedése a fogászatban természetszerúleg együtt jár a fogászati 2D és 3D képfelvételek számának növekedésével. Korábban a gipszmintákat nehéz volt tartósan eltárolni a fizikai térfogatuk és törékenységük miatt. A modellek hosszú távú tárolása megkönnyíti a páciens panaszát követő jogi ügyek megoldását, és egyes büntetőügyekben segítheti a harapásnyomok elemzését (Khatri et al. 2013). Kevésbé ismert, hogy ezek a nyilvántartások az emberi azonosításra is felhasználhatók.

A röntgenfelvételek általában „.jpg” fájlkiterjesztéssel rendelkeznek. A 3D fogászati minták fájlkiterjesztése az „.stl” fájl. Az „.stl”-t a 3D-tervező rendszerek használják, és a jármúiparban is ismert, háromszögekből álló
1. táblázat |A 2D-és 3D-leletek fájlkiterjesztési típusai és méretei

\begin{tabular}{lllr}
\hline Képfelvétel típusa & Példa & Fájlkiterjesztés & $\begin{array}{l}\text { Átlagos méret } \\
\text { (byte) }\end{array}$ \\
\hline 2D panoráma rtg. & 1. ábra A kép & .jpg & 401000 \\
2D periapicalis rtg. & 1. ábra B kép & .jpg & 180000 \\
3D teljes minta & 1. ábra C-D kép & .stl & 33000000 \\
3D szájpadlásminta & 4. ábra képei & .stl & 7000000 \\
3D egy fog & 1. ábra E kép & .stl & 1200000 \\
\hline
\end{tabular}

háromdimenziós felület megjelenítésére alkalmas. Az 1 . táblázat az egyes fájlkiterjesztéseket, képfelvételi típusokat, valamint méretüket foglalja össze.

A felhőben történő adattárolás mellett fontos, hogy az eltárolt adat milyen minőségú. Ezzel arányos, hogy a megfelelő minőség mekkora tárhelyigényt foglal magában. Amennyiben jogi, rehabilitációs és azonosítási szempontokat is figyelembe veszünk, akkor a 3D teljes fogas minta az egyik legfontosabb eltárolásra kerülő adat. Amennyiben csak biztonsági aspektusát tekintjük az azonosításnak és adattárolásnak, figyelembe véve az elfoglalt tárhelymennyiséget, úgy a szájpadlásbordázat, valamint a szájpadlásmélység, -magasság és -szélesség paraméterei adják a legjobb megoldást.

A nehézséget országszerte az jelenti, hogy a szájszkennerek még a rendelők többségében nincsenek jelen, elsősorban magas áruk miatt. Áthidaló megoldást jelenthet, hogy a hagyományos lenyomatvételt követő kiöntött minta kerül laborszkenner segítségével digitalizálásra a

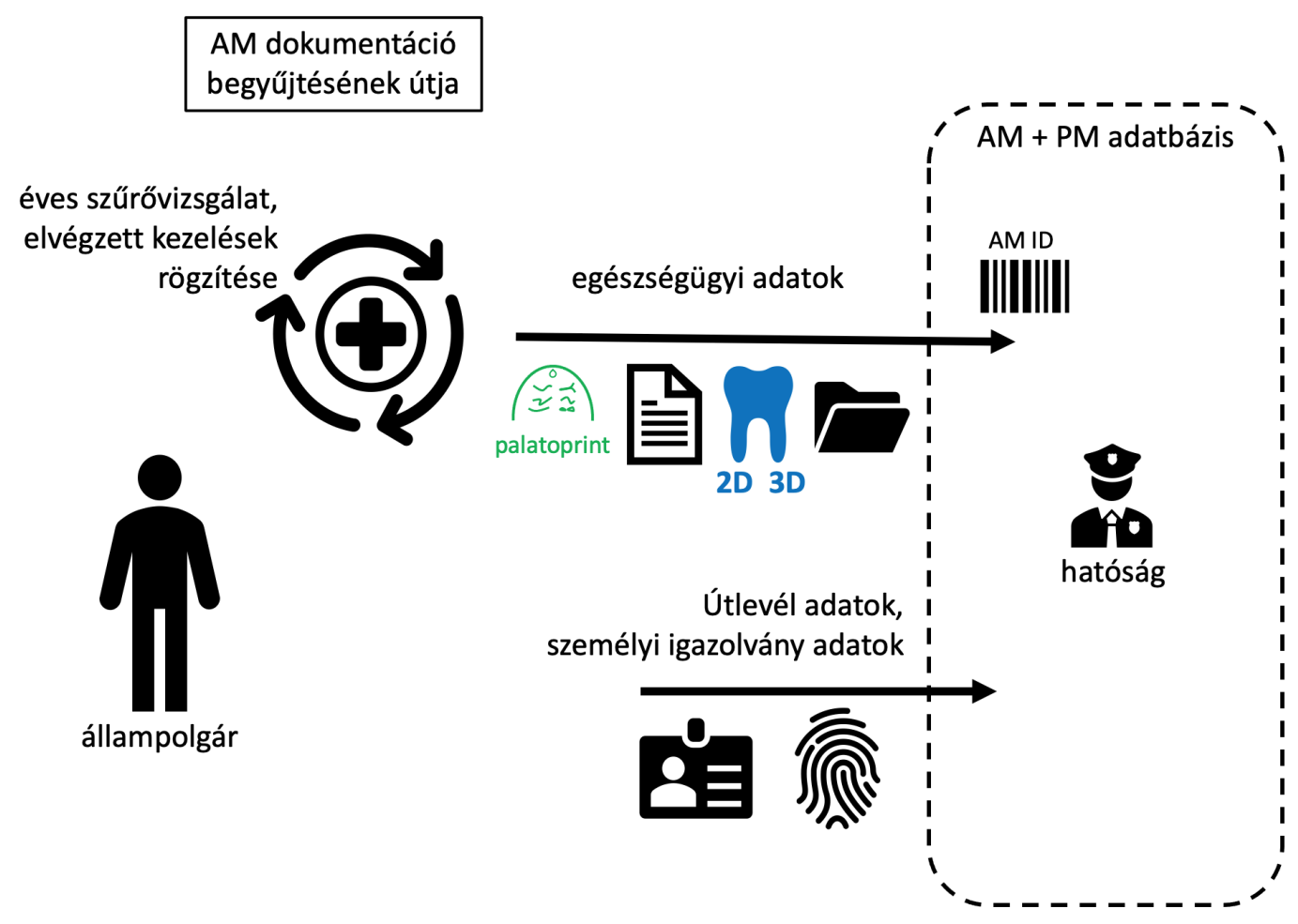

\begin{tabular}{l|l} 
3. ábra & $\begin{array}{l}\text { AM-dokumentáció begyújtésének útja } \\
\text { Forrás: A szerző saját ábrája }\end{array}$
\end{tabular} 
fogtechnikus által, amely szintén megfelelő módon segíti az AM-PM-adatok összevetését.

A megfelelő minőségú ante-mortem dokumentáció begyưjtésének útjait ábrázolja a 3. ábra.

Az állampolgárról az éves fogászai szűrővizsgálatok és az elvégzett fogászati kezelések alkalmával rendelkezésre állnak egészségügyi információk, amelyek azonosítás szempontjából relevánsak. Továbbá a 2D, 3D fogászati leletek, amilyen a röntgenlelet vagy a lenyomat, szájpadlás-információk (palatoprint), kezelőorvos adatai is segítik az áldozatazonosítást. Az összevetés és az adatok egymáshoz kapcsolása miatt fontos az útlevélhez és személyi igazolványhoz tartozó azonosítási információk rögzítése. Az így összegyújtött adatok az AM + PM adatbázisban tárolódnak QR-kód (Singh et al. 2013; Syed et al. 2016) vagy vonalkód segítségével, a GDPR előírásainak megfelelően. Ennek köszönhetően a preventív adatbázis felépíthető, ahogy a 3. ábrán látható.

Fontos az eltünt személyek egészségügyi adatait az adatbázishoz kapcsolni, amennyiben még nincs korábbi regisztráció az eltûnt személyról. Amennyiben pedig van, akkor az adatbázisban hatósági oldalon címkét kell létrehozni. Ez azért fontos, mert a keresést lerövidítheti, amennyiben nyílt esemény történt, és ismeretlen személytől származik a minta (Salado Puerto-Tuller 2017). A PM-dokumentáció hasonló típusú információkat kell tartalmazzon, mint az AM-dokumentáció során begyưijtött adatok (3. ábra). Az ismeretlen személy azonosítása felgyorsítható a preventív adatbázisnak köszönhetően, mivel a korábban begyújitött AM-dokumentáció megfelelő minőségű és releváns információt tartalmaz. A PMadatok ugyanúgy azonosító kódot kapnak, amely később az összevetéskor segíti a szakértők munkáját. A teljes folyamat a 4. ábrán látható.

Az AM ID és a PM ID összevetésével és az egyező azonosító párok megtalálásával sikeresen azonosítható az ismeretlen holttest. Az azonosítási procedúrát követően a halotti bizonyítvány kiállítható, a hatóságok és a hozzátartozók pedig lezárhatják az ügyet. Fontos, hogy kegyeleti okok miatt minél hamarabb eltemetésre kerüljön az áldozat, a hozzátartozók pedig a gyászt megélhessék (5. ábra).

\section{A szájpadlásbordák felhasználása emberi azonosításra}

Az ujjnyomat-azonosításnak jelentős a társadalmi elfogadottsága, ugyanakkor az ujjnyomat-azonosításnak megvannak a gyakorlati hátrányai is, mivel az ujjvégeken található bőr sérülékeny, szöveti tulajdonságából adódóan égési sérülésre, szándékos roncsolásra, deformálódásra, valamint intenzív felázásra nem ellenálló, így felületében irreverzibilis károsodás keletkezik (Holder et al. 2011).

A fogászati azonosítás tömegkatasztrófa esetén sokkal nagyobb százalékkal bizonyul sikeresnek (Schuller-Götzburg 2016), mint az ujjnyomat- vagy DNS-azonosítás (Schou-Knudsen 2012).

Bizonyítani tudtuk, hogy a szájpadbordák felhasználhatók emberi azonosításra (Simon et al. 2020), életünk során stabil képletek, így egyszerre ötvözik az ujjnyomat, a DNS és a fogak jó tulajdonságait, mégis az adatgyújtés és az összevetés könnyen megoldható a fogászati szakma bevonásával. Méréseinkkel az is kimutatható volt, hogy a szájpadlásnak mint lágyszövetnek 17 éves kortól kezdve

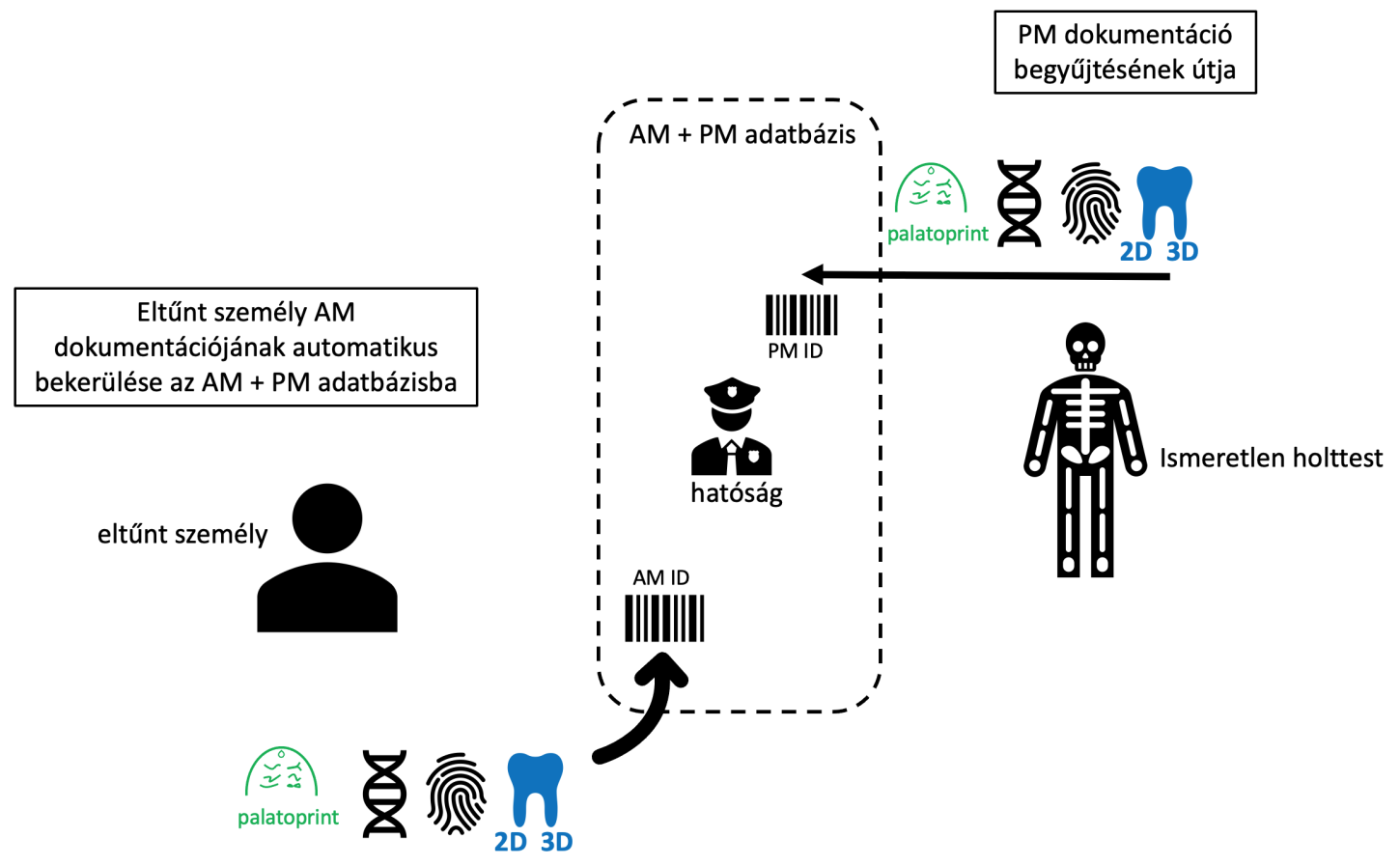

4. ábra $\quad$ A PM-adatok begyújtésének és eltưnt személy AM-dokumentációjának útja

Forrás: A szerző saját ábrája 


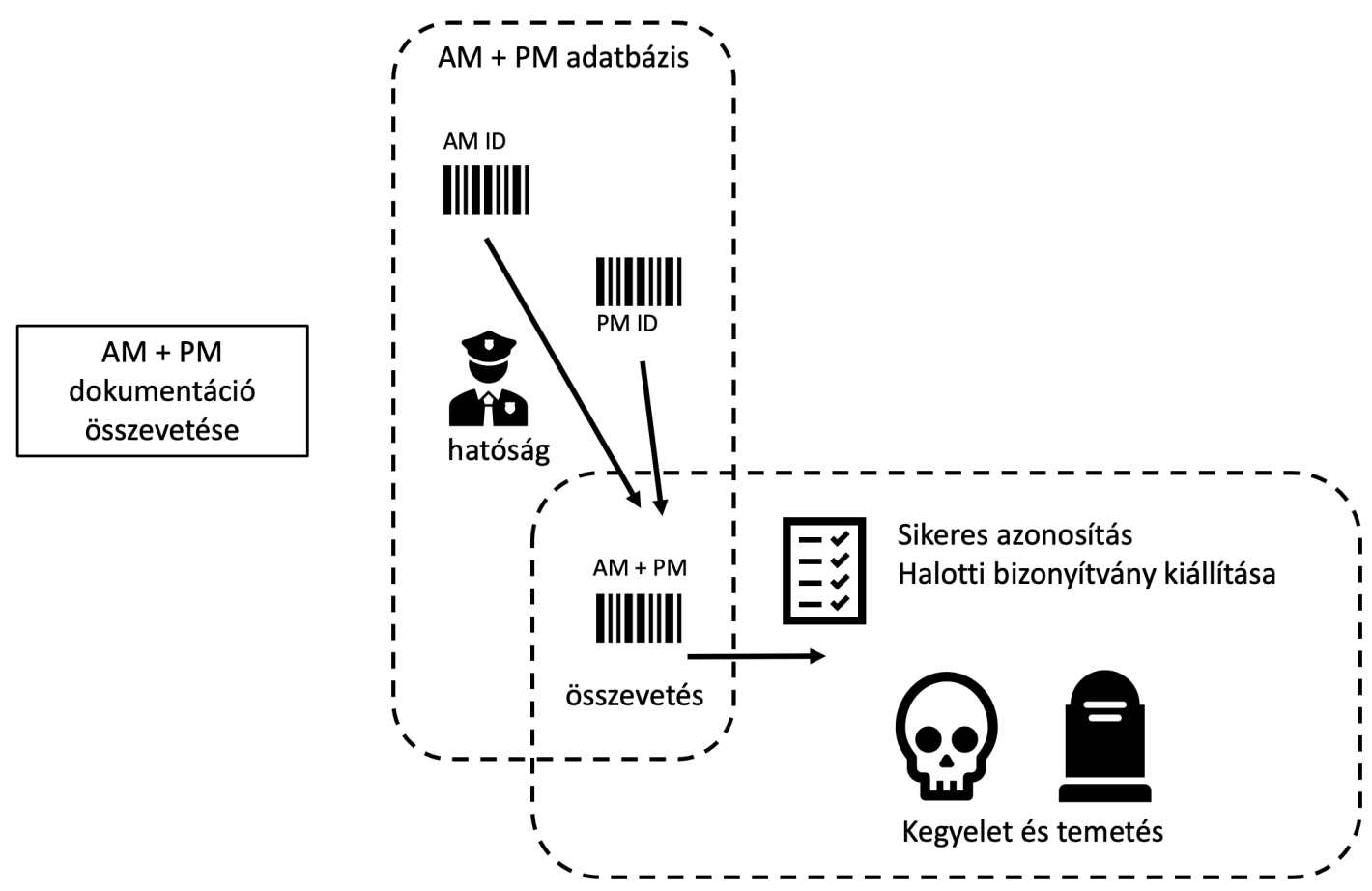

$\mathbf{A}$
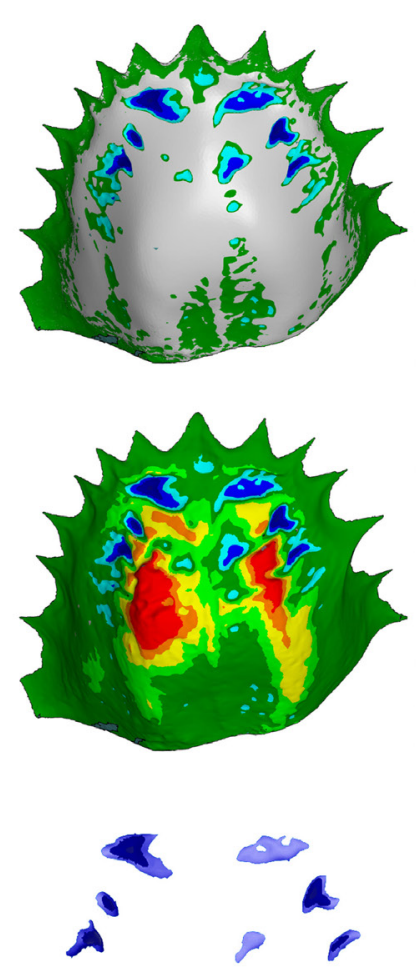

B
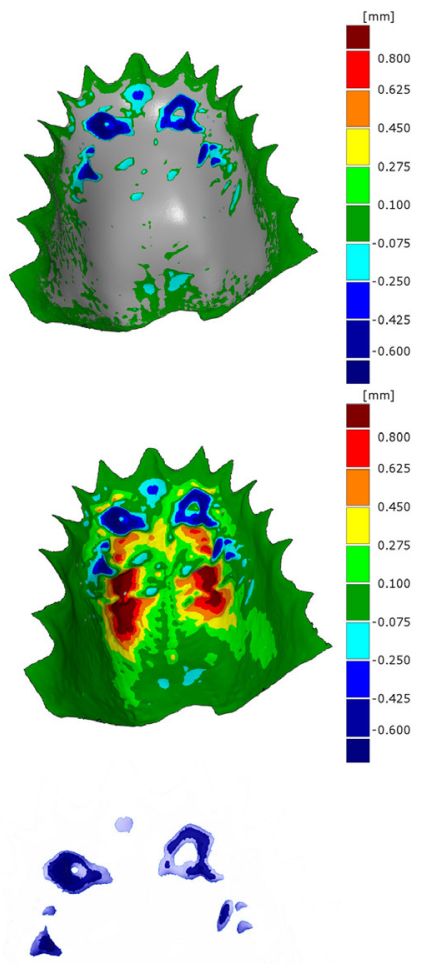

C
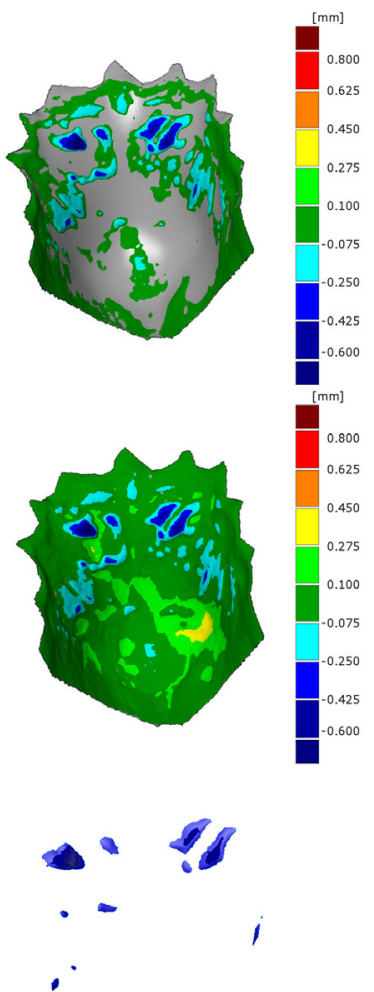

6. ábra

Minden oszlopban egy-egy különböző személy szájpadlásmintája látható (A, B, C oszlop). Az első sorban a módosított (szürke), valamint eredeti (színes) szken egymásra helyezése látható, ahol a sötétkék színek jelölik a szájpadbordák kiemelkedéseit a két minta egymásra helyezését követően. A második sorban a színhőtérkép jelzi, hogy a simítási algoritmus az eredeti mintát pozitív (vörös) vagy negatív (kék) tartomány felé módosította. Látható, hogy azokon a területeken, ahol nincsenek szájpadbordák, a simítás a felszínt szignifikáns mértékben nem változtatta meg (zöld terület). A harmadik sorban a szájpadbordák kiemelkedései láthatók, amely az ujjnyomathoz hasonló egyedi megjelenést ad különböző személyek esetében.

Forrás: A szerző saját ábrája 
$3 \mu \mathrm{m}$ a szöveti degradációs folyamata, amely 50 éves távlatban még mindig kis eltérést mutat, így szignifikánsan nem befolyásolja az azonosítást (Simon et al. 2020).

A 6. ábrán látható, hogy ugyanannak a személynek a digitális háromdimenziós szájpadlásmintájáról a szájpadbordákat szoftveres módon eltüntetve (smoothing), majd az eredeti és módosított szájpadlásmintát egymásra helyezve kirajzolható a szájpadbordák domináns, kiemelkedő megjelenése, amelyet egy új klasszifikációs rendszerbe helyezve az ujjnyomathoz hasonló azonosítási protokoll hozható létre (Holder et al. 2011).

\section{Összefoglalás}

A tömegkatasztrófa-helyzetek bekövetkezését előre megjósolni nem lehet, azonban a nem várt eseményekre bizonyos mértékig fel lehet készülni. Az állam szempontjából elengedhetetlen, hogy tömegkatasztrófa-helyzetre gyorsan tudjon reagálni, képzett szakembereket vezényeljen a helyszínre, akik megkezdhetik a kármentést, az áldozatazonosítást, valamint a mihamarabbi helyreállítást. A terepen dolgozó igazságügyi szakértók folyamatosan versenyt futnak az idővel, ezért fontos, hogy olyan áldozatazonosítást segítő rendszerek álljanak a hatóság számára rendelkezésre, amelyek nagy hatékonysággal, megbízható módon, rövid idő alatt képesek nagyszámú áldozat azonosítására, az anyagi és emberi erőforrás minimalizálásával. A jelenlegi áldozatazonosítás reaktív alapokra épül, amely azt jelenti, hogy az esemény bekövetkezésére reagál az azonosításért felelős szerv, az antemortem információk begyüjtése mindig a katasztrófa után történik, amely rontja az áldozatazonosítás valószínúségét. Az ante-mortem információ bizonytalan, hogy valóban kellő minőségben és mennyiségben rendelkezésre áll, a kezelőorvos elérhetó-e, a tárolt adatok megfelelőek-e az azonosításra. A megoldást pedig a reaktív alapokról a preventív alapokra épülő áldozatazonosítási adatbázis felépítése jelenti, amely proaktív módon tud reagálni a bekövetkező eseményre azáltal, hogy a begyűjtött post-mortem információ azonnal összevetésre kerül az adatbázisban található ante-mortem információkkal. Amint a 3., 4. és 5. ábrán is látható, a preventív azonosítási adatbázis felépítése és múködése komplex folyamat, amely az állami és magánegészségügyi szolgáltatóktól együttmúködést kíván annak érdekében, hogy az állam biztosítani tudja állampolgárainak a hatékony fellépést áldozatazonosítás esetén. Az állampolgár biztonságát tekintve fontos, hogy megértse, egy ilyen rendszer a saját érdekét is szolgálja. Az EESZT és egy okos rendszer öszszehangolása pedig a preventív áldozatazonosítási adatbázis mellett a preventív szemléletmóddal rendelkező egészségügyi rendszert is támogatja, hiszen általános alapigazság, hogy prevencióba fektetni hosszú távon az állam szempontjából olcsóbb, az állampolgárok szem- pontjából kifizetődőbb, és nemcsak a tudatosságot, hanem a biztonságot is növeli.

Ehhez az alapot a digitális fogászati technológiák fejlódése, a szájszkennerek pontosságának fejlesztése jelentheti (Nagy et al. 2020; Vag et al. 2019), amely folyamatos szoftveres fejlesztéssel (Vag et al. 2021) javíthat az adatfelvétel minőségén. Az éves fogorvosi szúrővizsgálatot a felnőtt lakosság részben igénybe veszi, egyes európai országokban évente többször, míg Magyarországon évente 0,7 alkalommal megy a felnőtt lakosság fogorvoshoz (Csákó 2020), függetlenül attól, hogy az elmúlt 10 évben közel 2,5 szeresére emelkedett a friss diplomás fogorvosok száma (Csákó 2020). Tehát gyakorlatilag a fogászati szakma bevonásával lehetséges a preventív azonosítási adatbázis felépítése, amelyhez az adatot az éves fogászati szưrővizsgálatok szolgálják, és a közeljövőben pedig a digitális fogászati technológia fejlődésével háromdimenziós adatgyújtés és központi adattárolás történhet. A nevelési-oktatási intézményeknél és a honvédeknél alkalmazott éves szürővizsgálat is kiegészülhet digitális háromdimenziós szájszkenneléssel. A honvédek esetén ez pontos képet adna a fogazati státuszukról, gyorsabbá és könnyebbé tenné az emberi azonosítást, amennyiben bevetés során szükség lenne rá. A szájszkennerek hordozható mobil eszközök, így akár terepen is alkalmazhatók. Használatuk komoly szakmai háttértudást nem igényel, felhasználóbarát és a tanulási folyamat gyors.

Magyarország jó alapokkal rendelkezik ahhoz, hogy úttörő szerepe legyen egy preventív, fogászati és áldozatazonosítási adatbázis felépítésében. Az EESZT részére nyújtott kötelező adatszolgáltatás az első mérföldkő. A következő mérföldkő a fogászati szakma nagyarányú digitalizációja, valamint kötelezése digitális háromdimenziós adatrögzítő eszközök, azaz szájszkennerek használatára. Ehhez olyan támogatási rendszer kidolgozása szükséges, amellyel a digitalizáció pár év alatt maradéktalanul bekövetkezhet. Első körben az oktatási-nevelési intézményeknél és honvédeknél végzett éves szưrővizsgálathoz fontos biztosítani a szájszkennereket, majd kiterjeszteni a magánszektorra is támogatások útján.

Kutatócsapatunk a Semmelweis Egyetemmel, a SCRUNCH Kft.-vel és az Autsoft Zrt.-vel közösen már dolgozik egy mintázatfelismerő algoritmus kifejlesztésén, amely a DVI egységek munkáját segíti a jövőben, de az informatikai fejlesztés megfelelő állami szerepvállalás és szabályozás, valamint jogi környezet megteremtése nélkül csak hosszú idő alatt érné el célját.

A preventív és proaktív fogászati azonosítás bevezetése és jelentősége áldozatazonosítás esetén a közeljövőben felértékelódik, mert egyszerre segíti a DVI egységek munkáját, növeli az állampolgárok biztonságtudatosságát, valamint reprezentálja az adaptív digitális állam létrehozására törekvést. 


\section{Irodalomjegyzék}

(1997a) 26/1997. (IX. 3.) NM rendelet az iskola-egészségügyi ellátásról. https://net.jogtar.hu/jogszabaly?docid=99700026.nm [Letöltve: 2021. 04. 11.]

(1997b) 1997. évi CLIV. törvény az egészségügyről. https://net.jog tar.hu/jogszabaly?docid=99700154.tv\# [Letöltve: 2021 . 04. 11.]

(2013) 2013. évi CXXVII. törvény egyes egészségügyi és egészségbiz tosítási tárgyú törvények módosításáról. https://mkogy.jogtar.hu/ jogszabaly?docid=al300127.TV [Letöltve: 2021. 04. 11.]

(2015) HM rendelet a katonai szolgálatra való egészségi, pszichikai és fizikai alkalmasságról, valamint a felülvizsgálati eljárásról. https:// net.jogtar.hu/jogszabaly?docid=a1500010.hm [Letöltve: 2021 . 04. 11.]

(2016a) 2016 Berlin truck attack. https://en.wikipedia.org/ wiki/2016_Berlin_truck_attack [Letöltve: 2021.04. 11.]

(2016b) 2016 Nice truck attack. https://en.wikipedia.org/ wiki/2016_Nice_truck_attack [Letöltve: 2021.04. 11.]

(2016c) 2016-os brüsszeli terrortámadás. https://hu.wikipedia.org/ wiki/2016-os_br\%C3\%BCsszeli_terrort\%C3\%Almad\%C3\%Als [Letöltve: 2021. 04. 11.]

(2017a) 2017-es katalóniai terrortámadások. https://hu.wikipedia. org/wiki/2017-es_katal\%C3\%B3niai_terrort\%C3\%Almad\%C3\%Alsok [Letöltve: 2021. 04. 11.]

(2017b) 2017-es stockholmi terrortámadás. https://hu.wikipedia. org/wiki/2017-es_stockholmi_terrort\%C3\%Almad\%C3\%Als [Letöltve: 2021. 04. 11.]

(2019a) Christchurch mosque shootings. https://en.wikipedia.org/ wiki/Christchurch_mosque_shootings [Letöltve: 2021.04. 11.]

(2019b) Ethiopian Airlines Flight 302. https://en.wikipedia.org/ wiki/Ethiopian_Airlines_Flight_302 [Letöltve: 2021.04. 11.]

(2019c) Hableány hajóbaleset. https://hu.wikipedia.org/wiki/2019es_budapesti_haj\%C3\%B3katasztr\%C3\%B3fa [Letöltve: 2021. 04 11.]

(2020a) 2020 Beirut explosion. https://en.wikipedia.org/wiki/ 2020_Beirut_explosion [Letöltve: 2021.04.11.]

(2020b) 2020-as bécsi terrortámadás. https://hu.wikipedia.org/ wiki/2020-as_b\%C3\%A9csi_terrort\%C3\%Almad\%C3\%Als [Letöltve: 2021.04 .11 .]

(2020c) Nemzeti Adatvagyon Ügynökség. https://kormany.hu/hi$\mathrm{rek} /$ megalakult-a-nemzeti-adatvagyon-ugynokseg

https://digitalisjoletprogram.hu/hu/hirek/megalakult-a-nemzetiadatvagyon-ugynokseg

https://neum.hu/information.html [Letöltve: 2021. 04. 11.]

(202la) EESZT. https://hu.wikipedia.org/wiki/EESZT [Letöltve: 2021. 04. 11.]

(2021b) Implantátumregiszter tájékoztató. https://impreg.neak.gov. hu/ [Letöltve: 2021.04. 11.]

(2021c) Passenger train carrying 490 derails in Taiwan, killing at least 50 and injuring dozens. https://edition.cnn.com/2021/04/01/ asia/taiwan-train-derail-intl-hnk/index.html [Letöltve: 2021. 04 11.]

Absolonova, K., Dobisíková, M., Beran, M., Zocová, J., \& Veleminsky, P. (2012) The temperature of cremation and its effect on the mic rostructure of the human rib compact bone. Anthropologischer Anzeiger; Bericht über die biologisch-anthropologische Literatur, Vol. 69. No. 4. pp. 439-460.

Alexander, D. E. (2014) Social Media in Disaster Risk Reduction and Crisis Management. Science and Engineering Ethics, Vol. 20. No. 3. pp. 717-733.

Angyal, M., \& Petrétei, D. (2019a) Az Interpol DVI-protokoll-adaptációjával a hazai áldozatazonosítás fejlesztésének útján. Nemzetbiztonsági Szemle, Vol. 7. No. 1. pp. 3-17.

Angyal, M. \& Petrétei, D. (2019b) A Magyarországi Áldozatazonosítási Szolgálat felállításának kihívásai és tapasztalatai. Budapest, Nemzeti Közszolgálati Egyetem
Azab, S. M. S., Magdy, R., \& Sharaf El Deen, M. A. (2016) "Patterns of palatal rugae in the adult Egyptian population." Egyptian Journal of Forensic Sciences, Vol. 6. No. 2. pp. 78-83.

Chong, J. A., Syed Mohamed, A. M. F., Marizan Nor, M., \& Pau, A. (2020) The Heritability of Palatal Rugae Morphology Among Siblings*†. Journal of Forensic Sciences, Vol. 65. No. 6. pp. 20002007.

Csákó, B. (2020) Fogászati eljárás, fogorvosok. https://www.parlament.hu/documents/10181/4464848/Infojegyzet_2020_48_ fogaszati_ellatas.pdf/14db03a5-0567-1036-a046-5ced2d10cbbf?t =1590654613571, [Letöltve: 2021. 04. 11.]

Elani, H. W., Starr, J. R., Da Silva, J. D., \& Gallucci, G. O. (2018) Trends in Dental Implant Use in the U.S., 1999-2016, and Projections to 2026. J Dent Res, Vol. 97. No. 13. pp. 1424-1430.

Houston, J. B., Hawthorne, J., Perreault, M. F., Park, E. H., Gold stein Hode, M., Halliwell, M. R., Turner Mcgowen, S. E., Davis, R., Vaid, S., Mcelderry, J. A., \& Griffith, S. A. (2015) Social media and disasters: a functional framework for social media use in disaster planning, response, and research. Disasters, Vol. 39. No. 1. pp. 1-22.

Identification Guide. https://www.interpol.int/How-we-work/ Forensics/Disaster-Victim-Identification-DVI, [Letöltve: 2021. 04. 11.]

Kapali, S., Townsend, G., Richards, L., \& Parish, T. (1997) Palatal rugae patterns in Australian Aborigines and Caucasians. Australian Dental Journal, Vol. 42. No. 2. pp. 129-133.

Khatri, M., Daniel, M. J., \& Srinivasan, S. V. (2013) A comparative study of overlay generation methods in bite mark analysis. J Forensic Dent Sci, Vol. 5. No. 1. pp. 16-21.

Kommalapati, R. K., Katuri, D., Kattappagari, K. K., Kantheti, L. P. C., Murakonda, R. B., Poosarla, C. S., Chitturi, R. T., Gontu, S. R., \& Baddam, V. R. R. (2017) Systematic Analysis of Palatal Rugae Pattern for Use in Human Identification between Two Different Populations. Iran J Public Health, Vol. 46. No. 5. pp. 602607

Limson, K. S., \& Julian, R. (2004) Computerized recording of the palatal rugae pattern and an evaluation of its application in forensic identification. J Forensic Odontostomatol, Vol. 22. No. 1. pp. 1-4.

Martini, M., Bufalari, I., Stazi, M. A., \& Aglioti, S. M. (2015) Is That Me or My Twin? Lack of Self-Face Recognition Advantage in Identical Twins. PLOS ONE, Vol. 10. No. 4. pp. e0120900

Meskó, B., Drobni, Z., Bényei, É., Gergely, B., \& Győrffy, Z. (2017) Digital health is a cultural transformation of traditional healthcare. mHealth, Vol. 3. pp. 38-38.

Monden, C., Pison, G., \& Smits, J. (2021) Twin Peaks: more twinning in humans than ever before. Human Reproduction, https://doi. org/10.1093/humrep/deab029

Nagy, Z., Simon, B., Mennito, A., Evans, Z., Renne, W., \& Vag, J. (2020) Comparing the trueness of seven intraoral scanners and a physical impression on dentate human maxilla by a novel method. BMC Oral Health, Vol. 20. No. 1. pp. 97.

National Institute of Justice (2011) The Fingerprint Sourcebook. https://www.ojp.gov/ pdffiles1/nij/225320.pdf

NATO (2017) Dental Fitness Standards for Military Personnel and the NATO Dental Fitness Classification System. NATO Standardization Office (NSO). https://www.coemed.org/files/stanags/03_ AMEDP/AMedP-4.4_EDA_V2_E_2466.pdf [Letöltve: 2021. 04. 11.]

Palen, L., \& Hughes, A. L. (2018) Social Media in Disaster Communication. Handbook of Disaster Research, pp. 497-518. DOI: 10.1007/978-3-319-63254-4_24

Pinchi, V., Norelli, G. A., Caputi, F., Fassina, G., Pradella, F., \& Vincenti, C. (2012) Dental identification by comparison of antemortem and postmortem dental radiographs: influence of operator qualifications and cognitive bias. Forensic Sci Int, Vol. 222. No. 1-3. pp. 252-255. 
Pison, G., Monden, C., \& Smits, J. (2015) Twinning Rates in Developed Countries: Trends and Explanations. Population and Development Review, Vol. 41. No. 4. pp. 629-649.

Salado Puerto, M., \& Tuller, H. (2017) Large-scale forensic investigations into the missing: Challenges and considerations. Forensic Sci Int, Vol. 279. pp. 219-228.

Schou, M. P., \& Knudsen, P. J. (2012) The Danish Disaster Victim Identification effort in the Thai tsunami: organisation and results. Forensic Sci Med Pathol, Vol. 8. No. 2. pp. 125-130.

Schuller-Götzburg, P. (2016) Forensisch-odontologische Identifizierung der Opfer des Flugunfalls Zell am See. Rechtsmedizin, Vol. 26. No. 1. pp. 34-41.

Schuller-Götzburg, P., \& Suchanek, J. (2007) Forensic odontologists successfully identify tsunami victims in Phuket, Thailand. Forensic Sci Int, Vol. 171. No. 2-3. pp. 204-207.

Schuller-Götzburg, P., Suchanek, J., \& Gugler, J. (2005) Identifizierung der Tsunamiopfer im Thai Tsunami Victim Identification-Information Management Center (TTVI-IMC) in Phuket, Thailand. Österreichische Zeitschrift für Stomatologie, Vol. 102. No. 4. pp. 109-113.

Simon, B., Liptak, L., Liptak, K., Tarnoki, A. D., Tarnoki, D. L., Melicher, D., \& Vag, J. (2020) Application of intraoral scanner to identify monozygotic twins. BMC Oral Health, Vol. 20. No. 1. pp. 268

Singh, S., Bhargava, D., \& Deshpande, A. (2013) Dental orthopantomogram biometrics system for human identification. Journal of Forensic and Legal Medicine, Vol. 20. No. 5. pp. 399-401.

Suri, Cs. (2010) A fogászati és szájsebészeti ellátás szervezési, valamit klinikai elveinek változása a NATO követelményeinek teljesítése érdekében. Zrínyi Miklós Nemzetvédelmi Egyetem Kossuth Lajos Hadtudományi Kar Hadtudományi Doktori Iskola, https://nkerepo.uni-nke.hu/xmlui/bitstream/handle/123456789/12207/ tezis_hun.pdf? sequence $=2$

Syed, S., Alshahrani, I., Alshahrani, A., Togoo, R. A., Luqman, M., \& Dawasaz, A. A. (2016) Conversion of palatal rugae pattern to scan- able Quick Response code in an Arabian population. Journal of Dental Sciences, Vol. 11. No. 3. pp. 253-260.

Taneva, E., Evans, C., \& Viana, G. (2017) 3D Evaluation of Palatal Rugae in Identical Twins. Case Rep Dent, 2017, pp. 2648312.

Taneva, E. D., Johnson, A., Viana, G., \& Evans, C. A. (2015) 3D evaluation of palatal rugae for human identification using digital study models. J Forensic Dent Sci, Vol. 7. No. 3. pp. 244-252.

Tao, X., Chen, X., Yang, X., \& Tian, J. (2012) Fingerprint recognition with identical twin fingerprints. PLoS One, Vol. 7. No. 4. pp. e35704.

United Nations Office for Disarmament Affairs (2020) Human Cost of Disasters. https://doi.org/10.18356/79b92774-en, https:// www.un-ilibrary.org/content/books/9789210054478

Vag, J., Nagy, Z., Simon, B., Mikolicz, A., Kover, E., Mennito, A., Evans, Z., \& Renne, W. (2019) A novel method for complex threedimensional evaluation of intraoral scanner accuracy. Int J Comput Dent, Vol. 22. No. 3. pp. 239-249.

Vag, J., Renne, W., Revell, G., Ludlow, M., Mennito, A., Teich, S. T., \& Gutmacher, Z. (2021) The effect of software updates on the trueness and precision of intraoral scanners. Quintessence Int, DOI: $10.3290 /$ j.qi.b1098315

Vanderveken, A., Guha-Sapir, D. \& McClean, D. (2016) Poverty \& Death: Disaster Mortality, 1996-2015. Centre for Research on the Epidemiology of Disasters - The United Nations Office for Disaster Risk Reduction. https://www.researchgate.net/publication/311317900_Poverty_Death_Disaster_Mortality_1996-2015

Vieira, D., Ribeiro, C., Pinto, R., \& Durão, C. (2012) Importance of a national arthroplasty register for identification by medical examiner. Revista Brasileira de Ortopedia, Vol. 47. pp. 651-655.

Willis, A. J., \& Myers, L. (2001) A cost-effective fingerprint recognition system for use with low-quality prints and damaged fingertips. Pattern Recognition, Vol. 34. No. 2. pp. 255-270.

A cikk a Creative Commons Attribution 4.0 International License (https://creativecommons.org/licenses/by/4.0/) feltételei szerint publikált Open Access közlemény, melynek szellemében a cikk bármilyen médiumban szabadon felhasználható, megosztható és újraközölhető, feltéve, hogy az eredeti szerző és a közlés helye, illetve a CC License linkje és az esetlegesen végrehajtott módosítások feltüntetésre kerülnek. (SID_1) 